\title{
The Quality of Superior Seedless Bunches during Shelf Life as Determined by Growth on Different Rootstocks
}

\author{
A. A. Lo'ay $^{1}$ (D) Hamed Ismail ${ }^{2}$ and Hazem S. Kassem ${ }^{3, *(D)}$ \\ 1 Pomology Department, Faculty of Agriculture, Mansoura University, Mansoura 35516, Egypt; \\ Loay_Arafat@mans.edu.eg \\ 2 Department of Food Science, University of Guelph, Guelph, ON N1G-2W1, Canada; ismailh@uoguelph.ca \\ 3 Department of Agricultural Extension and Rural Society, College of Food and Agriculture Sciences, King \\ Saud University, Riyadh 11451, Saudi Arabia \\ * Correspondence: hskassem@ksu.edu.sa; Tel.: +966-581045671
}

Citation: Lo'ay, A.A.; Ismail, H.; Kassem, H.S. The Quality of Superior Seedless Bunches during Shelf Life as Determined by Growth on Different Rootstocks. Agriculture 2021, 11, 990. https: / / doi.org/10.3390/ agriculture11100990

Academic Editors: Georgios Tsaniklidis and Dimitrios Fanourakis

Received: 2 September 2021

Accepted: 8 October 2021

Published: 11 October 2021

Publisher's Note: MDPI stays neutral with regard to jurisdictional claims in published maps and institutional affiliations.

Copyright: (c) 2021 by the authors. Licensee MDPI, Basel, Switzerland. This article is an open access article distributed under the terms and conditions of the Creative Commons Attribution (CC BY) license (https:// creativecommons.org/licenses/by/ $4.0 /)$.

\begin{abstract}
Vineyard rootstocks are an important tool in the local and international market for growing the Superior Seedless grape cultivar, which is highly favored by customers. As a result, it is vital to pay close attention to the quality of clusters during handling. The current study aimed to determine whether Superior Seedless vines can be grown on specific rootstocks, resulting in higher quality during shelf life. Vines of the Superior Seedless vine cultivar that were used were 13 years old and had been grown on sandy soil. These vines were grafted onto four different rootstocks (genotypes), namely Freedom, 1103 Paulsen, SO4, and Own Root. The soluble solids content (SSC\%) was selected as $16 \%$. Bunches were subsequently stored in the lab at $27 \pm 1{ }^{\circ} \mathrm{C}$ with $57 \pm 3 \%$ air relative humidity for three days. Rootstock 1103 Paulsen's quality was found to be superior to that of the other rootstocks, according to the results of the study. Rootstock 1103 Paulsen maintained its ascorbic acid (AA) content, which is reflected in its antioxidant capacity, according to the results. In addition, lipid peroxidation accumulation and ion leakage percentages indicated that oxidative reactions were at their lowest levels. The results show that 1103 Paulsen decreases cellular metabolism enzyme activities at the shelf life level and improves the bunch quality of Superior Seedless (scion) grapes within 4 days of application. As a whole, the results show that the 1103 Paulsen rootstock produces Superior Seedless bunches of a high quality that is preserved throughout the shelf life period.
\end{abstract}

Keywords: seedless; shelf life; quality; rootstocks

\section{Introduction}

Viticulture is one of the oldest forms of cultivation, owing to the high export value and yield of grapes. Grapes are Egypt's second largest crop after citrus fruits in terms of cultivated area and productivity [1], where 73,351 hectares of land are used for the production of $1,626,259$ tons of grapes [2]. Numerous Seedless grape species mature in stages throughout the growing season (March to November) [3], which makes them ideal for cultivation on newly created sandy lands [4]. In the middle of the 19th century, rootstocks were used in vineyards to solve a number of problems [3]. Grafting is a technique used in horticultural orchards to connect various genotypes (rootstocks) with other types (scions) [5]. The primary issues to be addressed in this field are insect infestation (phylloxera), soil salinity tolerance, and drought (abiotic stress). Additionally, the physical and chemical characteristics of bunches, related to their yield and quantity, have been enhanced [6].

There are various rootstock selection methods currently used for the cultivation of Superior Seedless grapes, a fact that seems to be linked to the large diversity of soils and climates where these vines are grown [7]. Various studies with vineyards have demonstrated that rootstocks exert an important influence on the grafted cultivar in different aspects, such as growth, yield, and bunch quality [8]. Rootstocks can affect growth [9] and 
vine development [10] and influence vine canopy development by increasing leaf area and chlorophyll pigment content [11]. Furthermore, it was observed that the differences in the rootstocks of the grafted vines resulted in differences in the size, number [12], and volume of berries [13]. The rootstocks were also observed to have effects on berry quality, such as on berry firmness, separation force [14], and color during shelf life [15]. The impacts of rootstock on the total soluble solids content and on the total sugar contents were also determined [16] and found to influence SSC content in addition to organic acid [17] and phenolic compounds [18] in berries.

However, research on the influence of the rootstocks on the biochemical composition of Superior Seedless grapes is very limited, especially during storage under shelf life conditions. The purpose of this study is to determine the quality traits of the Superior Seedless grapes grown on Freedom, SO4, 1103 Paulsen, and Own Root rootstocks during its shelf life.

\section{Materials and Methods}

\subsection{Fruit Materials and Experimental Layout}

In Sadat City, Monufia, Egypt $\left(31.23^{\circ} \mathrm{N}, 29.96^{\circ} \mathrm{E}\right)$, a 13-year-old commercial orchard of Superior Seedless orchard was investigated. In sandy soil, $3 \mathrm{~m} \times 3 \mathrm{~m}$ rows of vines were planted. The vines were grafted using Freedom, SO4, 1103 Paulsen, and Own Root (control treatment) rootstocks. The following characteristics of rootstocks were used for Superior Seedless: Freedom $(1613 \mathrm{C} \times \mathrm{V}$. champini) is a vigorous (scion) cultivar with medium to high Phylloxera and nematode resistance, and it is moderately adapted to calcareous soil. The SO4 $(V$. berlandieri $\times V$. riparia) is highly resistant to Phylloxera and has medium nematode resistance and is moderately adapted to calcareous soil. The 1103 Paulsen ( $V$. berlandieri $\times V$. rupestris) is extremely vigorous, with medium nematode resistance and is adapted to calcareous soil [19]. Each rootstock used for the Superior Seedless cultivar was planted on an area of 50 hectares. Bunches were collected when the total soluble solids concentration (SSC \%) reached $16 \%$ at harvest time. Bunch harvesting commenced on 1 May 2019. Before arriving at the department, each of the 288 bunches had been divided into two groups. Bunches (288) were picked and delivered $3 \mathrm{~h}$ after harvest under cooling at $13{ }^{\circ} \mathrm{C}$. They were divided into two main batches. The first batch (144 bunches) was used for determination of physical quality attributes, i.e., water loss, berry shattering, rachis browning, and berry color (hue angle). This batch was divided into $4 \times 36$ bunches each for rootstock/treatment, for which there were three replicates (e.g., $3 \times 12$ bunches). The second batch was used for the chemical analysis and had the same fruit distribution among the treatments, as previously described. Bunches were stored separately (each sample of rootstock was separate in a carton box at one layer) in the laboratory for three days at $27 \pm 1{ }^{\circ} \mathrm{C}$ and $57 \pm 3 \mathrm{RH} \%$. Both physical and chemical analyses were conducted daily until the end of the experiment.

\subsection{Physical Properties of Bunches}

Instead of using a plunger to determine berry firmness (BF), a hook was used to estimate berry separation force (BSF). The berries were selected along the cluster axis every day to estimate their physical and chemical traits. The percentage of berry shattering and water loss were determined based on the initial bunch weight at harvest time [20]. Rachis browning in bunches appears as brown spots, which increase in number and size with the extension of shelf life duration. Rachis browning was inspected and scored on a scale from 0 (no browning) to 5 (very severe browning) based on area and browning intensity. The RB index was computed according to the methods of [21]. The berry color hue angle measurement was evaluated at intervals throughout the duration of storage via the method described in [22]. 


\subsection{Chemical Properties of Bunches}

The total soluble solids concentration (SSC\%) and tartaric acid content (TA\%) were determined using a Carl Zeiss hand refractometer [23], which was used to estimate the amount of ascorbic acid, and the SSC/TA ratio was calculated as a percentage [24].

\subsection{Cellular Metabolism Enzyme Activities}

Berry pedicels $(1 \mathrm{~g})$ were ground and homogenized in a solution of $20 \mathrm{mM}$ Tris- $\mathrm{HCl}$ at a $\mathrm{pH}$ of 7 . This mixture was centrifuged for at $15,000 \times \mathrm{g}$ for $20 \mathrm{~min} 4{ }^{\circ} \mathrm{C}$. The clear supernatant was stored at $-20{ }^{\circ} \mathrm{C}$ for two days to determine polygalacturonase (PG), xylanase (XYL), and cellulase (CEL) activities, which were monitored using galacturonic acid, xylose, and carboxymethyl cellulose, respectively [25]. Then, $200 \mathrm{~mL}$ of sodium acetic acid derivation buffer ( $\mathrm{pH}$ 5), $100 \mathrm{~mL}$ of sodium chloride, and $300 \mathrm{~mL}$ of polygalacturonic acid were added to the reaction mix ( $1000 \mathrm{~mL}$ total volume). The substrate expanded, eliciting a response. The reaction mixture was incubated in a water bath for one hour at $37^{\circ} \mathrm{C}$. Then, $500 \mu \mathrm{L}$ dinitro salicylic acid reagent was added to the mixture, which was incubated in the water bath for $10 \mathrm{~min}$. As a result, the cooled clear samples reached room temperature prior to being used. A spectrophotometer was used to determine the absorbance of the PG, XYL, and CEL mixtures at 560 and $540 \mathrm{~nm}$. One unit of activity was defined as the amount that releases $1 \mu \mathrm{M}$ of diminishing sugar per minute at $37^{\circ} \mathrm{C}$.

Pectinase activity is indicated by PT. To determine the PT, $500 \mu \mathrm{L}$ of $0.36 \%$ polygalacturonic acid was mixed with $0.05 \mathrm{M}$ of Tris-HCL at $\mathrm{pH} 8.5,300 \mu \mathrm{L}$ of $4 \mathrm{mM} \mathrm{CaCl}_{2}, 600 \mu \mathrm{L}$ of protein, and $600 \mu \mathrm{L}$ of water. The findings were extremely encouraging. To allow reaction, the mixture was incubated at $37^{\circ} \mathrm{C}$ for $3 \mathrm{~h}$ before measuring. In this way, the PT could be determined by measuring the absorbance at $232 \mathrm{~nm}$ [26]. The activities of the enzymes are expressed in $\mathrm{mol} \mathrm{s}^{-1} \mathrm{~kg}^{-1}$.

The total protein was prepared and analyzed to determine the catalyst activity [27].

\subsection{Estimation of Phenolic Compounds and Browning Enzyme Activities}

The activities of the enzymes were determined by adding $1 \mathrm{~g}$ of rachis to $5 \mathrm{~mL}$ of Tris- $\mathrm{HCl}$ solution, adjusting the $\mathrm{pH}$ to 7 , and then mixing. The mixture was centrifuged at $10,000 \times g$ for $10 \mathrm{~min}$ at $4{ }^{\circ} \mathrm{C}$, and the clear supernatant was stored at $-20{ }^{\circ} \mathrm{C}$ to record the PPO activity. The enzyme activity was monitored using a catechol substrate. Then, in a matter of minutes, $200 \mathrm{~L}$ of the rachis extraction was added to $3 \mathrm{~mL}$ of $20 \mathrm{mM}$ catechol melted in $100 \mathrm{mM}$ sodium phosphate buffer at $\mathrm{pH}$ 7.0. Spectrophotometric readings collected at a wavelength of $400 \mathrm{~nm}$ over a three-minute period were used to determine activity. Catalysts containing one unit of PPO activity resulted in a 0.10 difference in absorbance per minute [28].

To determine the phenylalanine ammonia-lyase activity, $1 \mathrm{~g}$ rachis was added to $50 \mathrm{mM}$ borate buffer ( $\mathrm{pH}$ 8.5) containing $5 \mathrm{mM}$ 2-mercaptoethanol and $400 \mathrm{mg}$ PVP (PAL). The clear mixture was obtained by centrifuging at $16,000 \times \mathrm{g}$ for $15 \mathrm{~min}$ at $4{ }^{\circ} \mathrm{C}$. The desired result was obtained by adding $700 \mathrm{~L}$ of L-phenylalanine and $3 \mathrm{~mL}$ of $50 \mathrm{mM}$ borate buffer to the blend $(\mathrm{pH} 8.5)$ followed by immediate supplementing with $300 \mathrm{~L}$ of the supernatant fraction. The blend was stored for $60 \mathrm{~min}$ at $40^{\circ} \mathrm{C}$. By adding $100 \mathrm{~mL}$ of $\mathrm{HCl}(5 \mathrm{mM}$ final concentration), it was possible to inhibit the enzyme response. PAL activity was estimated at room temperature [29]. The activities of the enzymes are expressed in $\mu \mathrm{mol} \mathrm{s}{ }^{-1} \mathrm{~kg}^{-1}$.

Total phenolics (TP) were analyzed spectrophotometrically at a wavelength of $750 \mathrm{~nm}$. The data were calculated and expressed as mg of gallic acid equivalent (GAE) per $100 \mathrm{~g}$ of flavonoids [30].

\subsection{Malondialdehyde (MDA) and Electrolyte Leakage (EL\%)}

Two grams of berry tissue was used to measure malondialdehyde (MDA). With the help of the TABR test, the amount of lipid peroxidation in was determined. The homogenized mixture contains $2.5 \mathrm{~g}$ of berry tissue, $5 \%$ metaphosphoric acid $(w / v$ of HPO3), and $2 \%$ butyl hydroxytoluene (BHT; $\mathrm{C}_{15} \mathrm{H}_{24} \mathrm{O}$ ). As a result, a standard curve 
was prepared using 1,1,3,3-tetraethyoxypropane $\left(\mathrm{C}_{7} \mathrm{H}_{16} \mathrm{O}_{4}\right.$; Sigma-Aldrich, St. Louis, MO, USA), which is comparable to 0-1 mM malondialdehyde (MDA), to estimate the MDA accumulation of kumquat peel during storage [31]. The MDA was presented at a concentration of $\mathrm{nmol} \mathrm{kg} \mathrm{k}^{-1}$.

Samples were taken at intervals to estimate the electrolyte leakage (EL) during the shelf life period. Rachis $(2 \mathrm{~g})$ were added to $10 \mathrm{~mL}$ of $6 \mathrm{M}$ mannitol and kept for $3 \mathrm{~h}$ at lab conditions. Next, a conductivity meter was used to measure the conductivity of the solution (M1). All cuvettes were boiled for $1 \mathrm{~h}$ at $100{ }^{\circ} \mathrm{C}$ to destroy the peel tissue. The conductivity of all cuvettes was then reread as total leakage (M2). Ion leakage relativity was calculated as a percentage [32].

\subsection{Statistical Analysis}

The experiment was designed as a randomized complete block in two-way ANOVA with two factors: vine rootstocks as a treatment (four levels), and storage duration in days (three times) with three replicates per treatment. However, the parameters presented in Figure 1 were analyzed as a randomized complete block in one-way ANOVA when the rootstocks were a factor (measurements on the same bunches). The remaining variables were analyzed using the factorial design. The mean separations were run with Tukey's honestly significant difference test $(p \leq 0.05)$. Pearson's correlation matrix among the studied parameters and principal component analysis (PCA) were applied. Tukey's HSD test was run using the JMP Pro 16 software, with $p<0.05$ taken as indicating a statistically significant difference (SAS Institute, Cary, NC, USA). 


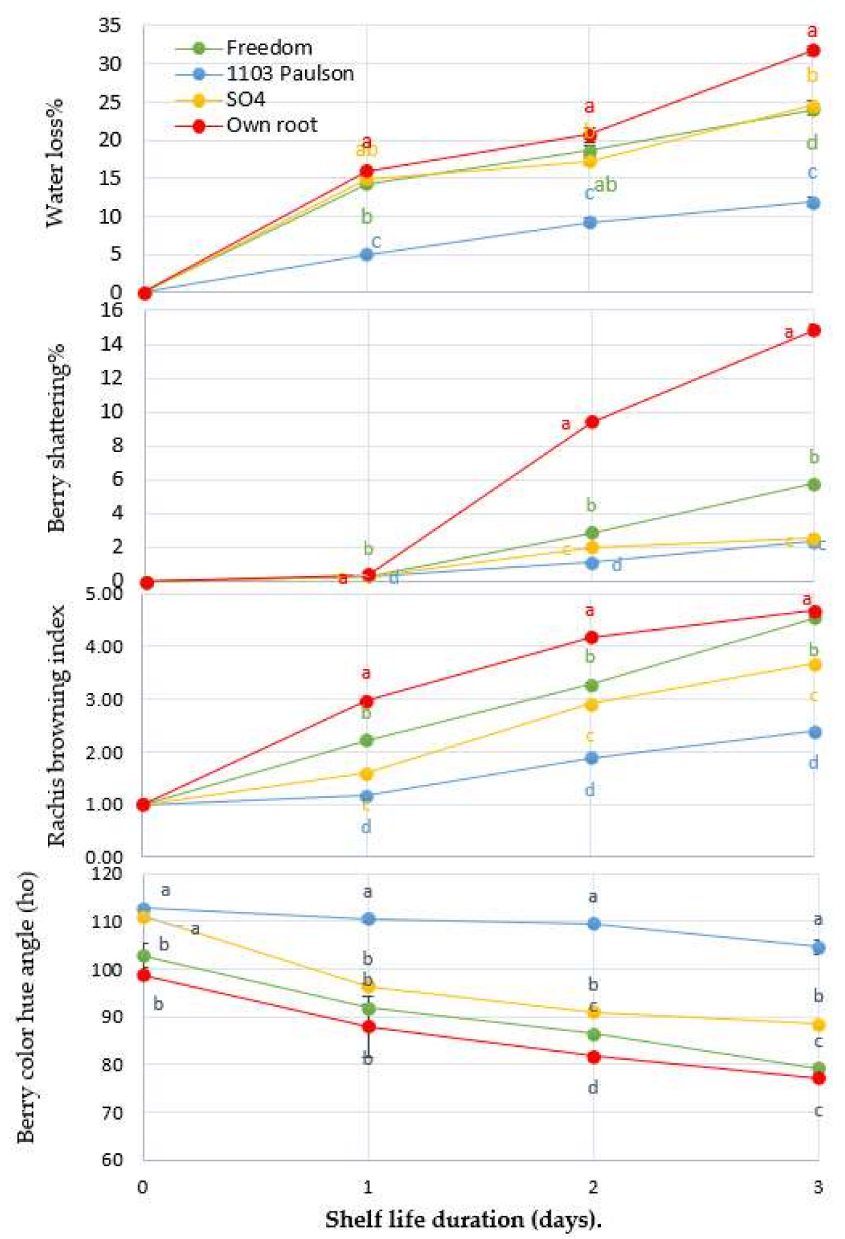

Figure 1. The effect of Superior Seedless grapevine rootstocks (Freedom, 1103 Paulsen, SO4, and Own Root) on water loss, rachis browning index, and berry color hue angle during three days of shelf life ( $27 \pm 1{ }^{\circ} \mathrm{C}$ with $\left.57 \pm 3 \% \mathrm{RH}\right)$. The vertical bars represent $\pm \mathrm{SE}(n=3)$, and significantly different samples, according to Tukey's HSD test at $5 \%$, are indicated by different letters.

\section{Results and Discussion}

3.1. Effect of Rootstocks on Physical Attributes: Water Loss\%, Rachis Browning Index (RB Index), and Berry Shatter \% (BS), and Color $\left(h^{\circ}\right)$

Figure 1 shows a significant difference $(p<0.05)$ in the physical quality attributes of Superior Seedless when the rootstocks were considered as a factor. Clearly, the 1103 Paulsen rootstock is more effective at reducing water loss compared to other rootstocks. The lowest percentage of water loss was observed on the second day of shelf life. The 1103 Paulsen rootstock led to a lower percentage (11.84\%) than that of Freedom (23.93\%), SO4 (24.62\%), and Own Root $(31.76 \%)$. The percentage of water loss of berries in all treatments increased gradually up to the end of the shelf life period. Notably, at harvest time, there was no evidence of berry shattering despite the low percentage on the second day of shelf life. On the third day of the shelf life, water loss was different due to the difference between rootstocks. The bunches picked from vines (superior seedless) grafted on 1103 Paulsen rootstock presented lower berry shattering $(2.31 \%)$ than those of the other rootstocks on the third day of the shelf life. Moreover, regarding rachis browning incidence, Figure 1 clearly shows that 1103 Paulsen presented low browning incidence throughout the 3 days of shelf life when compared to other rootstocks. When measuring the berry color, it was noted that bunches picked from vines grafted on the 1103 Paulsen rootstock resulted in better color retention compared to the other rootstocks. It recorded a higher degree of hue angle $\left(104.56 \mathrm{~h}^{\circ}\right)$, compared to bunches harvested from vines grafted on Freedom (79.17), SO4 (88.37), and Own Root $\left(77.12 \mathrm{~h}^{\circ}\right)$, respectively, on the third day of shelf life. 
These outcomes demonstrate that physical attributes can be affected differently by differences in rootstock. It seems probable that 1103 Paulsen rootstock has genetic determinants that affect water loss during shelf life [33]. Berries have a somewhat thick epidermis covered with a wax layer, which acts as a protective layer against dehydration. It could be that the 1103 Paulsen rootstock reduces water loss during shelf life by increasing the accumulation of wax on the berry surface during its development [22].

Furthermore, the difference between day and night temperatures may lead to cracks in the skin wax at the berry surface, which increases water loss during shelf life [33]. Previous results correlate with an increase in the percentage of berry shattering as a possible result of fungal infection during the storage period [33] which, as a consequence, causes a decrease in bunch water content [34]. Hence, berry shattering occurrence could be explained by the fact that the berry pedicel and brush behave in a climacteric process, showing respiration and ethylene peaks [35], with increasing hydrolysis due to the enhanced activity of cell wall degradation enzymes [1]. Therefore, a detachable layer is formed at the distal end of the berry pedicel [21].

Browning incidence is primarily linked to the oxidation of phenolic compounds by polyphenol oxidase (PPO) [36,37]. Thus, it could be that low rachis browning was observed on bunches of Superior Seedless (scion) due to the genetic effects of the 1103 Paulsen rootstock on the scion, as it contains a considerable amount of ascorbic acid, which could accumulate throughout berry maturation (Figure 2) and thereby minimize PPO activity during storage [38]. In accordance with previous findings, the increased loss of water from bunches constitutes cell stress, which leads to an increase in cell wall hydrolysis, so the percentage of berry shattering increases, as well as there being an increase in brown coloration on rachis. In this case, it could be concluded that the 1103 Paulsen rootstock endows Superior Seedless bunches with stress resistance during shelf life.

\subsection{Berry Firmness, Separation Force, and Ascorbic Acid Content}

According to Figure 2, the shelf life duration in days and rootstocks for measuring berry firmness (BF), separation force (BSF), and ascorbic acid content are significantly related $(p \leq 0.001)$. At the beginning of the experiment for all rootstocks, the BF, BSF, and AA were high at harvest time, and they gradually decreased during the experiment. In addition, it was easy to identify which rootstocks were Superior Seedless. At harvest time (day zero), the 1103 Paulsen rootstock had the highest values, which remained constant until the end of the storage period (third day). A BSF of $6.55 \mathrm{~N}$ and $239.33 \mathrm{mg} \mathrm{kg}^{-1}$ AA were measured at harvest time. After three days of storage, the highest values for $\mathrm{BF}$ (6.90), BSF $(5.98 \mathrm{~N})$, and AA (207.00 $\left.\mathrm{mg} \mathrm{kg}^{-1}\right)$ of all three components were observed. A more rapid decline was observed in all parameters for the other rootstocks when they were stored. 


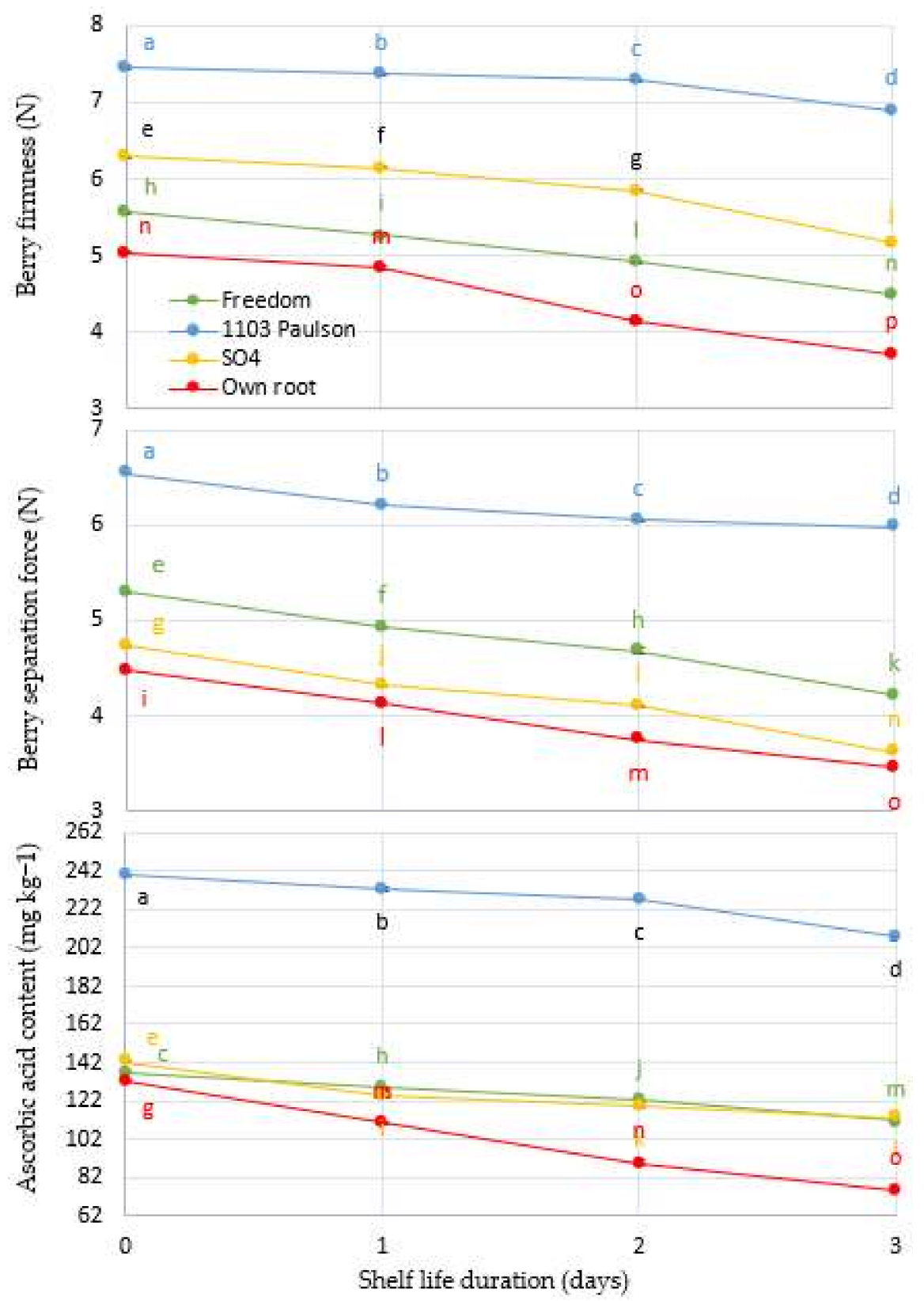

Figure 2. Interaction between Superior Seedless grapevine rootstocks (Freedom, 1103 Paulsen, SO4, and Own Root) and shelf life duration in days and effect on berry firmness, separation force, and ascorbic acid content during three days of shelf life $\left(27 \pm 1{ }^{\circ} \mathrm{C}\right.$ with $\left.57 \pm 3 \% \mathrm{RH}\right)$. Significantly different samples, according to Tukey's HSD test at $5 \%$, are indicated by different letters.

As compared to BSF and BF, Superior Seedless had significantly lower values. Firmness and separation force are the most important physical attributes that determine the consumer's acceptance of bunch quality. The brush and pedicels of berries have highly insoluble pectin content throughout the shelf life period, which could explain their good $\mathrm{BF}$ and BSF [39]. According to current literature, the 1103 Paulsen rootstock has the lowest percentage of water loss because of its direct effect on cellular wall degradation [40] and enzyme softening (Figure 1) [1]. The variance in berry firmness and separation, on the other hand, was directly related to the weight and water loss of bunches [41]. 
3.3. Effect of Rootstocks: Soluble Solids Concentration (SSC\%), Titratable Acidity (TA), and SSC/TA Ratio

For four Superior Seedless vine rootstocks, Figure 3 shows the adjustments of SSC\%, $\mathrm{TA} \%$, and the SSC/TA ratio as a function of shelf life duration in days. There is a significant $(p<0.001)$ interaction between the shelf time (days) and rootstocks when the previous parameters are taken into account. Compared to other rootstocks, vines grafted onto the 1103 Paulsen rootstock have the greatest impact at harvest. Vine rootstocks grafted onto the 1103 Paulsen rootstock were found to have a significant effect on both SSC and SSC/TA ratio compared to those other rootstocks, while TA\% had the highest initial value.

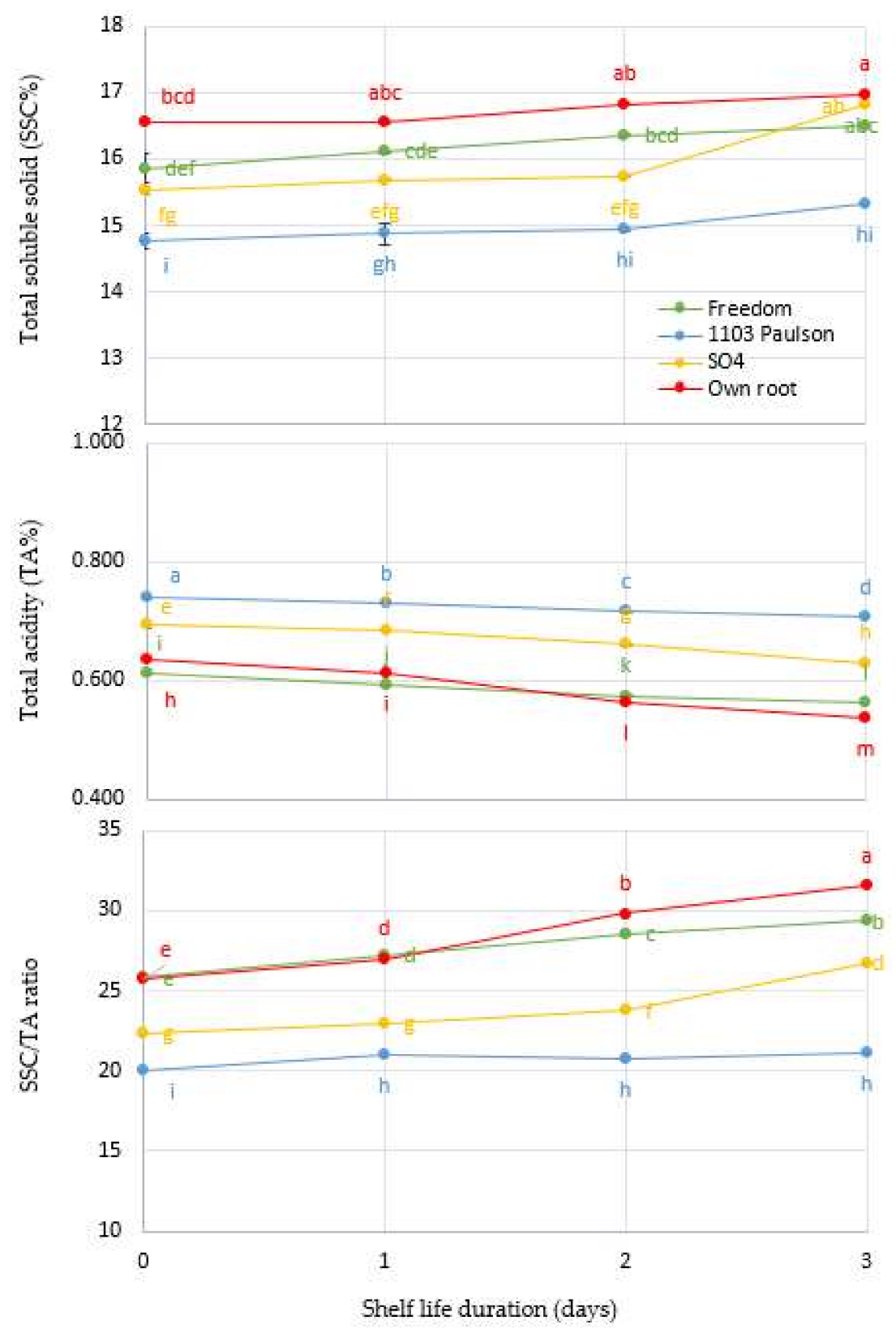

Figure 3. Interaction between Superior Seedless grapevine rootstocks (Freedom, 1103 Paulsen, $\mathrm{SO}_{4}$, and Own Root) and shelf life in days and effect on total soluble solids concentration (SSC\%), total acidity (TA\%), and SSC/TA ratio during three days of shelf life $\left(27 \pm 1{ }^{\circ} \mathrm{C}\right.$ with $\left.57 \pm 3 \% \mathrm{RH}\right)$. Significantly different samples, according to Tukey's HSD test at $5 \%$, are indicated by different letters.

The 1103 Paulsen rootstock is genetically related to Fame Seedless (scion), which is most likely the cause of the increase in TA\% [10]. Since the metabolism of carbohydrates 
is more active during berry development [42], and natural acid is more active during bunch maturation, harvest time variations in SSC\% are likely due to these factors [41]. We observed the low SSC\% and high acidity of the Superior Seedless grapes grafted on the 1103 Paulson. This may be due to the high acidity at harvest time and its decrease at a low rate compared to other rootstock effects, which reduced the deterioration of the clusters during the experimental period. Fruit acidity is a critical factor in increasing fruit quality since it affects how sourness and sweetness are perceived [43]. Furthermore, many species have reported that malic and citric acids play a vital role in influencing the acidity of mature fruit [44].

\subsection{Cellular Metabolism Enzyme Activities}

As shown in Figure 4, the XYL, CEL, PG, and PT levels in Superior Seedless bunches changed over the course of three days. $p \leq 0.001$ indicates an interaction between the rootstock effect and storage days, both factors that were experimentally studied. As a result of Superior Seedless vine rootstocks being harvested at harvest time, the enzyme activities initially differed from one another. The 1103 Paulsen rootstock had the lowest initial value of enzymes. They gradually increased until they reached their maximum activation peak on the third day after storage. Compared to other rootstocks, the rootstock 1103 Paulsen had the lowest activities for XYL (9.18), CEL (30.24), PG (2.24), and PT $\left(0.61 \mu \mathrm{mol} \mathrm{kg}{ }^{-1}\right)$ at harvest time. While the experiment was being conducted, it was also evident that the rootstock 1103 Paulsen was extremely stable. From the results of this study, it is evident that the 1103 Paulsen rootstock gave Superior Seedless bunches the ability to withstand four-day shelf life period (Figure 4). Due to the excessive awareness of antioxidants in bunches (scion) (Figure 2), antioxidants may be able to work together more effectively in a network [45]. A possible explanation for the stability of cellular enzyme activity during the entire storage period is that AA inhibits reactive oxygen species directly, making the other enzymes particularly effective in quenching free radical generation [46,47]. During the storage of Marsh cultivar, rootstocks were found to have an impact on enzyme activities [48].

\subsection{Phenolic Compounds and Browning Enzyme Activities}

According to Figure 5, phenolic compounds (phenols and TP and flavonoids (TFv)) differ in terms of their functions during the storage period, as do browning enzyme activities, such as polyphenol oxidase (PPO) and phenylalanine ammonia-lyase (PAL). There is a significant interaction $(p<0.05)$ between the browning variable and the shelf life period (days) when rootstock treatments are taken into account $(p \leq 0.001)$. It can be clearly observed that the phenolic compounds were significantly decreased compared to at the beginning of the project. The enzymes PPO and PAL, on the other hand, increased throughout the experimental period. Grafting onto the 1103 Paulsen rootstock was associated with a high content of total phenols and flavonoids, which were 4.31 and $3.21 \mathrm{mg} \mathrm{kg}^{-1}$, respectively, on the third day of shelf life. On the contrary, the TF and FVs for the other rootstocks decreased significantly during the shelf life period. For both TF and FVs, grafting onto the Own Root rootstock showed a greater reduction (1.49 and $1.48 \mathrm{mg} \mathrm{kg}^{-1}$, respectively) on the third days of shelf life when compared to the Freedom and SO4 rootstocks. Rootstock activity in the PPO and PAL groups, as well as the overall rootstock population, continuously increased until the end of the storage period. It was observed that the rootstock 1103 Paulsen had the lowest PPO and PAL activities on the third day of shelf life. PPO and PAL activities were the highest for the Own Root rootstocks at the end of an experiment at 0.24 and $5.96 \mu \mathrm{mol} \mathrm{s}^{-1} \mathrm{~kg}^{-1}$, respectively. PPO and PAL are known to be active because of the phenolic compounds TP and FL. This suggests that both PPO and PAL are involved in browning [33]. The synthesis of phenolic compounds may be affected by the genetic background of different rootstocks [10]. Previously, rootstocks were observed to have different effects on powdery mildew diseases, fungi, and insects [38]. Inhibition of PPO 
and PAL [49], as shown in Figure 1, may explain the decreases in both associated activities in the case of grafting onto 1103 Paulsen rootstock [50].

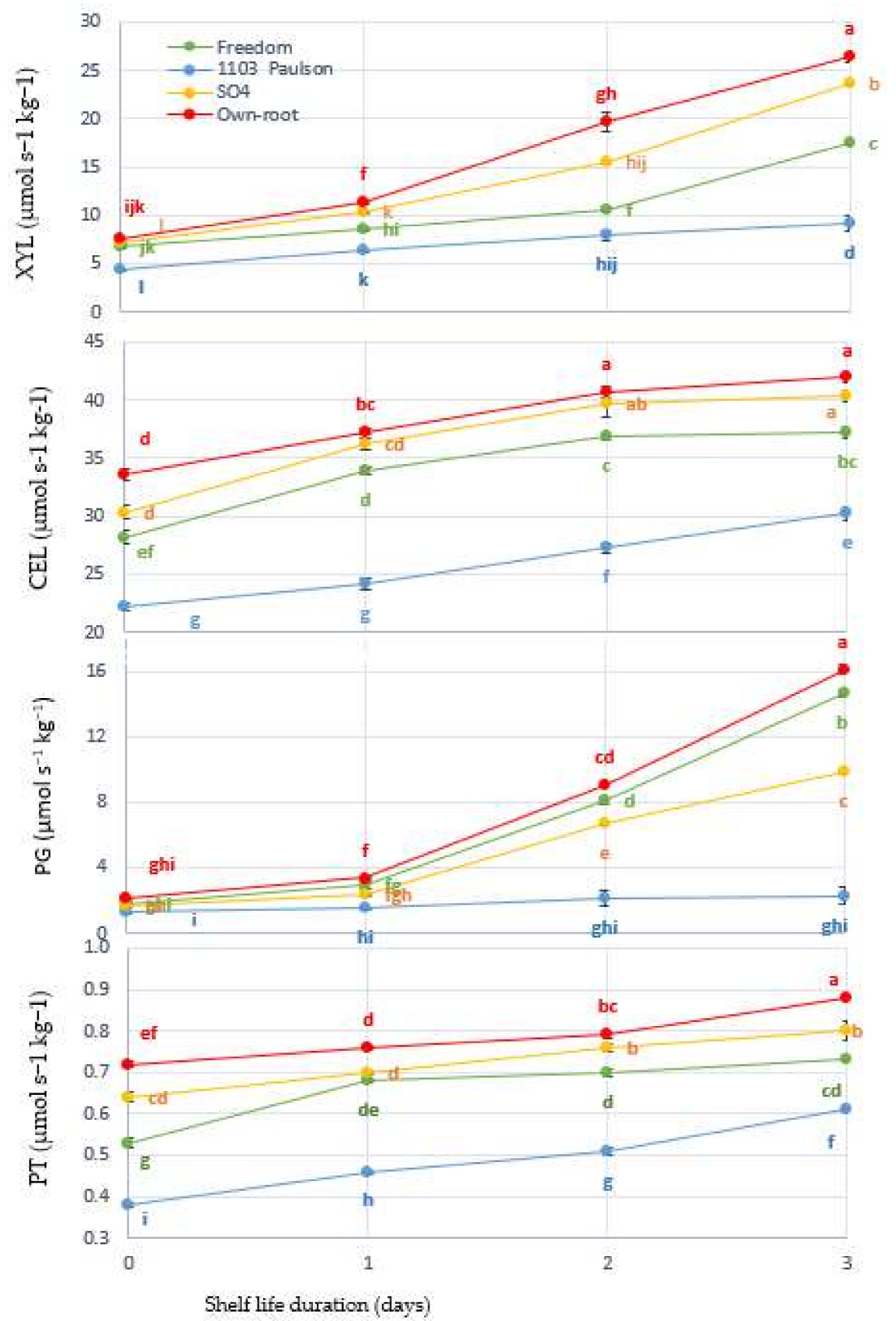

Figure 4. Interaction between Superior Seedless grapevine rootstocks (Freedom, 1103 Paulsen, SO4, and Own Root) and shelf life in days and effect on cellular metabolism enzyme activities such as xylanase (XYL), cellulase (CEL), polygalacturonase (PG), and pectinase (PT) during three days of shelf life $\left(27 \pm 1{ }^{\circ} \mathrm{C}\right.$ with $\left.57 \pm 3 \% \mathrm{RH}\right)$. Significantly different samples, according to Tukey's HSD test at $5 \%$, are indicated by different letters.

\subsection{Malondialdehyde (MDA) and Electrolyte Leakage \% (EL\%)}

MDA and cell plasma membrane degradation leakage (EL\%) are shown in Figure 6 for storage times in days. MDA and EL\% showed a significant interaction at $p \leq 0.001$, indicating that the two variables are interrelated. In addition to experimental factors, rootstocks were also studied. There was a significant interaction between MAD and EL\% $(p<0.05)$ when the experimental factors (days and rootstocks) were examined. First, at harvest time, there was a difference between the MDA and EL\% of the Superior Seedless rootstocks. 
All parameters increased independently, as the Superior Seedless vine rootstocks were used throughout the experiment.

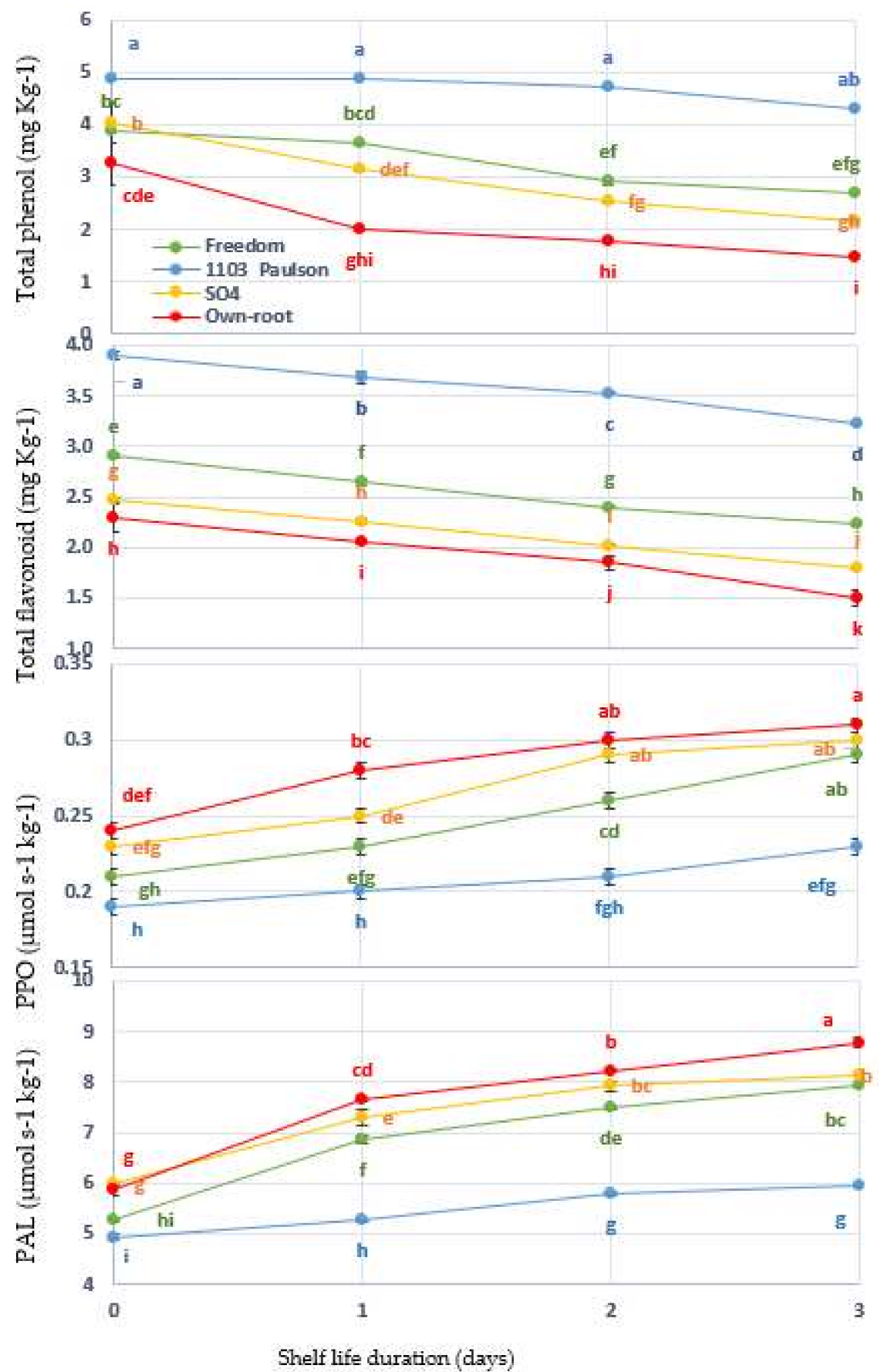

Figure 5. Interaction between Superior Seedless grapevine rootstocks (Freedom, 1103 Paulsen, SO4, and Own Root) and shelf life in days and effect on total phenol, flavonoid, poly phenol oxidase (PPO), and phenylalanine ammonia-lyase (PAL) during three days of shelf life $\left(27 \pm 1{ }^{\circ} \mathrm{C}\right.$ with $\left.57 \pm 3 \% \mathrm{RH}\right)$. Significantly different samples, according to Tukey's HSD test at $5 \%$, are indicated by different letters. 


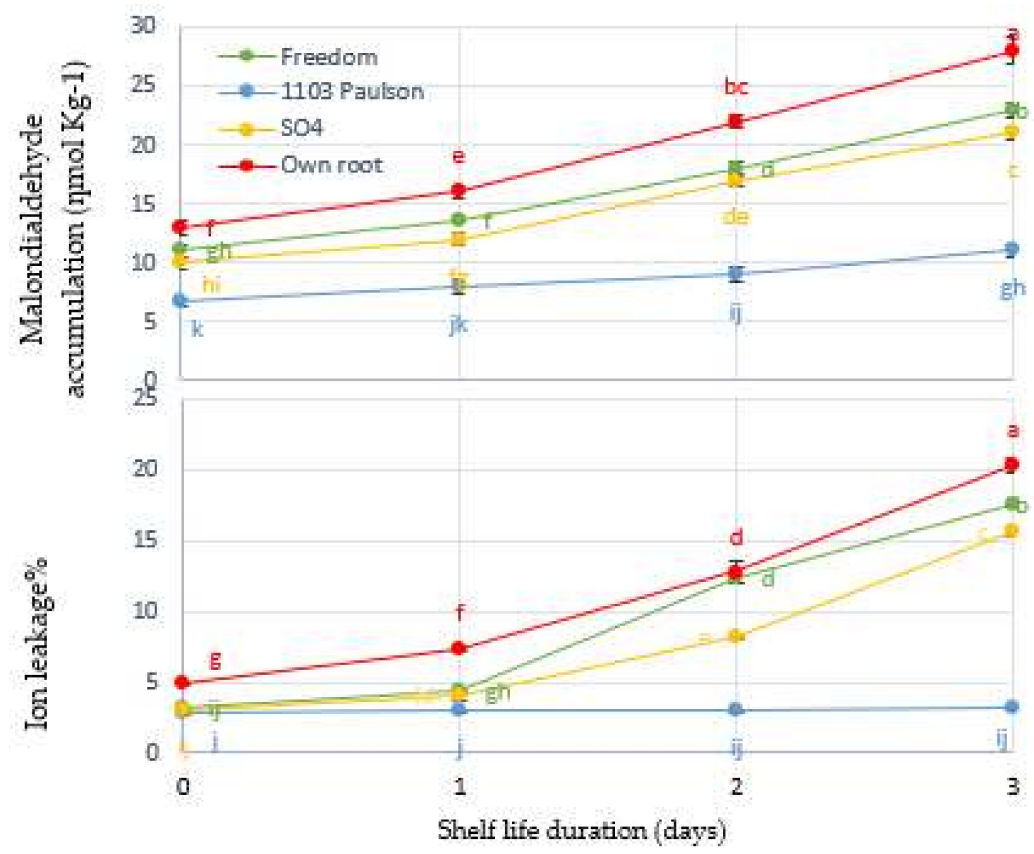

Figure 6. Interaction between Superior Seedless grapevine rootstocks (Freedom, 1103 Paulsen, $\mathrm{SO}_{4}$, and Own Root) and shelf life in days and the effect on malondialdehyde (MDA) and ion leakage \% during three days of shelf life $\left(27 \pm 1{ }^{\circ} \mathrm{C}\right.$ with $\left.57 \pm 3 \% \mathrm{RH}\right)$. Significantly different samples, according to Tukey's HSD test at $5 \%$, are indicated by different letters.

It is possible that ascorbic acid content affected both MDA and EL\% accumulation during storage [38]. It is also possible to infer from Superior Seedless vine rootstocks that the genetic variability between rootstocks is reflected in the amount of ascorbic acid [51]. Figure 2 shows that when using the rootstock 1103 Paulsen, the bunches (scion) accumulate ascorbic acid more so than for the other rootstocks. Since AA increases ROS scavenging, lipid peroxidation also increases [52]. However, ascorbic acid requires the activity of the cellular metabolism at a low state [53], which is linked to the reduction in MDA accumulation [54].

\subsection{Multivariate Analysis of Rachis Parameters}

Rootstocks used to develop Superior Seedless vines (Freedom, SO4, 1103 Paulsen, and Own Root) were subjected to a PCA for their effect on physiological and biochemical parameters of bunches. In the PCA, rootstocks and shelf life duration days were separated. PC1 described $78.5 \%$ of the data variability, while PC2 explained $12.75 \%$ (Figure 7A). As demonstrated in Figure 7B, there is a negative association between RB index and TFv, as well as a positive correlation between RB index and PPO. A link between the percentage of berries that shattered and cell metabolism was also observed. The other variables had a negative association with each of these four variables (BF, BSF, $\mathrm{WL} \%$, and $\mathrm{h}^{\circ}$ ).

There was a positive correlation between MDA concentration and EL\%, and a negative correlation between the BF and BSF levels, as well as the TV and TF levels. Pearson's correlation matrix revealed these findings as a result of the correlation between the studied parameters (Table 1). 
Table 1. Matrix showing Pearson's correlation between the studied parameters of Superior Seedless grape, which was grown on four different rootstocks, during shelf life.

\begin{tabular}{|c|c|c|c|c|c|c|c|c|c|c|c|c|c|c|c|c|c|c|c|}
\hline & WL\% & $\begin{array}{c}\text { RB } \\
\text { Index }\end{array}$ & BS\% & $h^{0}$ & XYL & CEL & PG & PT & BF & BSF & $\mathrm{SSC} \%$ & TA\% & SSC/TA\% & $\mathrm{TF}$ & TFv & PPO & PAL & EL\% & MDA \\
\hline W\% & * 1.0000 & & & & & & & & & & & & & & & & & & \\
\hline RB index & 0.8698 & 1.0000 & & & & & & & & & & & & & & & & & \\
\hline BS\% & 0.8762 & 0.8445 & 1.0000 & & & & & & & & & & & & & & & & \\
\hline$h^{\mathbf{o}}$ & -0.1044 & -0.1207 & 0.0410 & 1.0000 & & & & & & & & & & & & & & & \\
\hline XYL & 0.9083 & 0.8714 & 0.9549 & 0.1442 & 1.0000 & & & & & & & & & & & & & & \\
\hline CEL & 0.9027 & 0.8881 & 0.9512 & 0.1103 & 0.9706 & 1.0000 & & & & & & & & & & & & & \\
\hline PG & 0.7758 & 0.6834 & 0.7151 & 0.4199 & 0.8234 & 0.7723 & 1.0000 & & & & & & & & & & & & \\
\hline PT & 0.7311 & 0.6360 & 0.6839 & 0.4283 & 0.7872 & 0.7381 & 0.9378 & 1.0000 & & & & & & & & & & & \\
\hline BSF & -0.6582 & -0.6335 & -0.6469 & -0.5935 & -0.7652 & -0.7546 & -0.9272 & -0.8915 & 0.9062 & 1.0000 & & & & & & & & & \\
\hline SSC $\%$ & 0.7044 & 0.7808 & 0.6961 & 0.1403 & 0.7483 & 0.7141 & 0.7468 & 0.6973 & -0.7754 & -0.6941 & 1.0000 & & & & & & & & \\
\hline TA\% & -0.4331 & -0.4593 & -0.4346 & -0.7364 & -0.5836 & -0.5505 & -0.8332 & -0.8104 & 0.7968 & 0.9364 & -0.6351 & 1.0000 & & & & & & & \\
\hline SSC/TA\% & 0.5601 & 0.6243 & 0.5767 & 0.6088 & 0.6998 & 0.6685 & 0.8686 & 0.8235 & -0.8637 & -0.9341 & 0.8144 & -0.9601 & 1.0000 & & & & & & \\
\hline TF & -0.7030 & -0.6746 & -0.7206 & -0.5008 & -0.8299 & -0.7781 & -0.9291 & -0.8582 & 0.9427 & 0.9055 & -0.7519 & 0.8448 & -0.8934 & 1.0000 & & & & & \\
\hline TFv & -0.6400 & -0.5908 & -0.6561 & -0.6006 & -0.7808 & -0.7288 & -0.9508 & -0.9463 & 0.9326 & 0.9465 & -0.6980 & 0.9105 & -0.9109 & 0.9366 & 1.0000 & & & & \\
\hline PPO & 0.8259 & 0.7763 & 0.7933 & 0.2844 & 0.8985 & 0.8541 & 0.9365 & 0.8709 & -0.9531 & -0.8658 & 0.7346 & -0.7294 & 0.7943 & -0.9226 & -0.8943 & 1.0000 & & & \\
\hline PAL & 0.8654 & 0.7901 & 0.7719 & 0.2859 & 0.8763 & 0.8389 & 0.9497 & 0.8976 & -0.9200 & -0.8852 & 0.7848 & -0.7477 & 0.8255 & -0.9124 & -0.8826 & 0.9382 & 1.0000 & & \\
\hline EL\% & 0.9325 & 0.8691 & 0.8605 & 0.0761 & 0.9313 & 0.9253 & 0.8607 & 0.7838 & -0.8839 & -0.7963 & 0.7386 & -0.5845 & 0.6914 & -0.8244 & -0.7608 & 0.9283 & 0.9321 & 1.0000 & \\
\hline MDA & 0.9186 & 0.8902 & 0.8975 & 0.1205 & 0.9658 & 0.9460 & 0.8531 & 0.8176 & -0.8954 & -0.7818 & 0.7845 & -0.6124 & 0.7291 & -0.8365 & -0.8015 & 0.9182 & 0.9099 & 0.9484 & 1.0000 \\
\hline
\end{tabular}

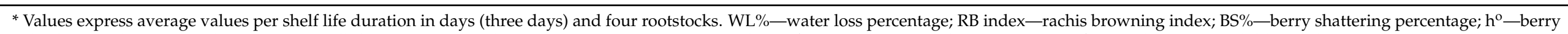

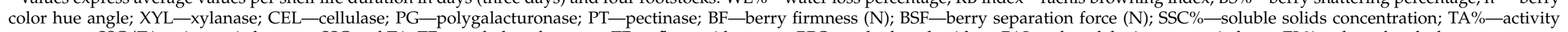

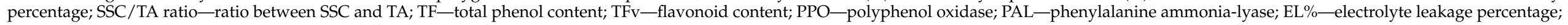

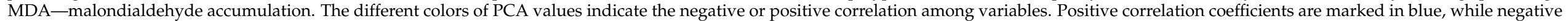
correlation coefficients are marked in red. 


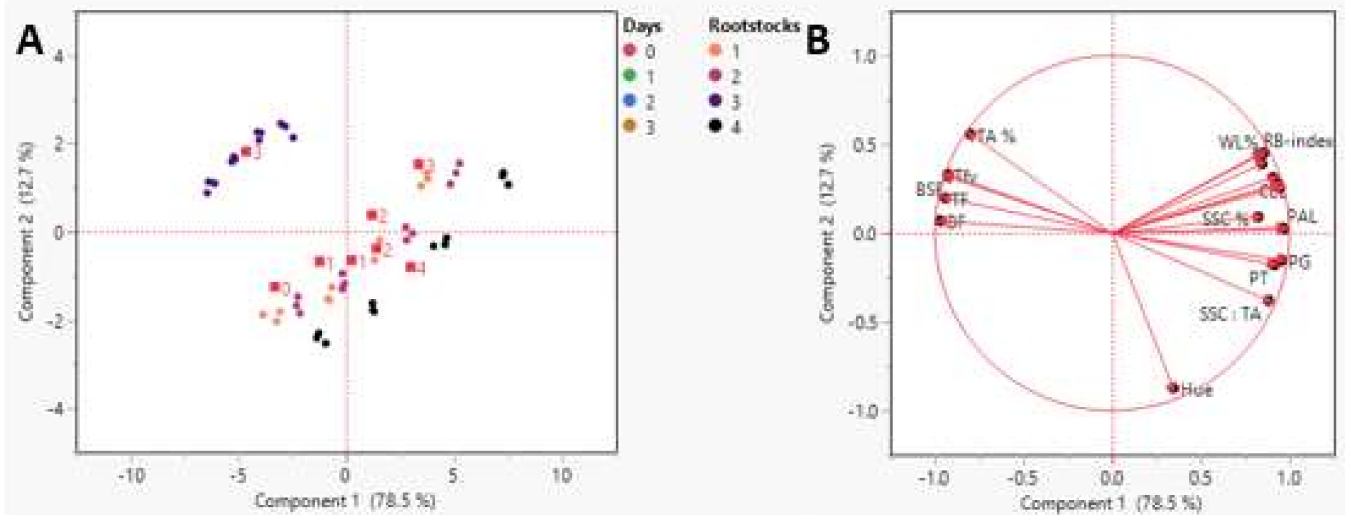

Figure 7. Principal component analysis (PCA) representing shelf life duration in days and four rootstocks of Superior Seedless grapes, plotted with the contribution of each parameter on the four PCA axes (A) and all of the physiological and biochemical parameters measured in bunches during the storage period (B). Principal component analysis (PCA) variable correlation.

\section{Conclusions}

The rootstocks on which Superior Seedless is grafted influence how bunches behave under three-day shelf life conditions. We discovered that the 1103 Paulsen rootstock assisted bunches in maintaining their physical and chemical properties throughout shelf life. Additionally, the results indicate that grafting the Superior Seedless vine onto the rootstock 1103 Paulsen resulted in the stabilization of the ascorbic acid content of the clusters during shelf life. Additionally, 1103 Paulsen had a significant effect on rachis browning and berry shattering. Our hypothesis is that ascorbic acid content stability during shelf life resulted in reduced activity of cell wall enzymes and browning enzymes (PPO and PAL). Unlike the other rootstocks, the grafting onto 1103 Paulsen was able to extend the shelf life of bunches up to the third day. Additional research is required to characterize the genetics of Superior Seedless rootstocks in order to determine whether they are more resistant to shelf life or marketing conditions than are other cultivars.

Author Contributions: Conceptualization, A.A.L.; data curation and validation, A.A.L.; methodology, A.A.L. and H.S.K.; formal analysis, A.A.L. and H.S.K.; writing-original draft preparation, A.A.L. and H.S.K.; writing-review and editing, H.I. All authors have read and agreed to the published version of the manuscript.

Funding: This research was funded by Researchers Supporting Project Number (RSP-2021/403), King Saud University, Riyadh, Saudi Arabia.

Institutional Review Board Statement: Not applicable.

Informed Consent Statement: Not applicable.

Data Availability Statement: Data is contained within the article.

Conflicts of Interest: The authors declare no conflict of interest.

\section{References}

1. El-Banna, M.F.; Lo'ay, A.A. Evaluation berries shattering phenomena of 'Flame seedless' vines grafted on different rootstocks during shelf life. Sci. Hortic. Amst. 2019, 246, 51-56. [CrossRef]

2. FAOSTAT. Source FAOSTAT. 2019. Available online: http://www.fao.org/faostat/en/\#data/QC (accessed on 19 August 2021).

3. El-Hady, E.S.; Shaltout, A.D.; Desouky, I.M.; Haggag, L.F. Characteristics of some grape cultivars as affected by some grape rootstocks. Middle East J. Agric. Res. 2014, 3, 609-617.

4. Kelany, A.E.; Abdel-Wahab, S.M.; Abdel-Hafeez, A.A.; Emam, I.A. Effect of pre-harvest treatments on cluster quality of flame seedless table grape cultivar during cold storage. J. Hortic. Sci. Ornam. Plants 2011, 3, 11-21.

5. Koepke, T.; Dhingra, A. Rootstocks scion somatogenetic interactions in perennial composite plants. Plant Cell Rep. 2013, 32, 1321-1337. [CrossRef] 
6. Lo'ay, A.A.; Doaa, M.H. The potential of vine rootstocks impacts on 'Flame Seedless' bunches behavior under cold storage and antioxidant enzyme activity performance. Sci. Hortic. 2020, 260, 108844. [CrossRef]

7. Jin, Z.-X.; Sun, T.-Y.; Sun, H.; Yue, Q.-Y.; Yao, Y.-X. Modifications of 'Summer Black' grape berry quality as affected by the different rootstocks. Sci. Hortic. 2016, 210, 130-137. [CrossRef]

8. Gao-Takai, M.; Katayama-Ikegami, A.; Nakano, S.; Matsuda, K.; Motosugi, H. Vegetative Growth and Fruit Quality of 'Ruby Roman' Grapevines Grafted on Two Species of Rootstock and Their Tetraploids. Hortic. J. 2017, 86, 171-182. [CrossRef]

9. Gijon, M.D.; Gimenez, C.; Perez-Lopez, D.; Guerrero, J.; Couceiro, J.F.; Moriana, A. Rootstock influences the response of pistachio (Pistacia vera L. cv. Kerman) to water stress and rehydration. Sci. Hortic. Amst. 2010, 125, 666-671. [CrossRef]

10. Koundouras, S.; Tsialtas, I.T.; Zioziou, E.; Nikolaou, N. Rootstock effects on the adaptive strategies of grapevine (Vitis vinifera L. cv. Cabernet-Sauvignon) under contrasting water status: Leaf physiological and structural responses. R. Agric. Ecosyst. Environ. 2008, 128, 86-96. [CrossRef]

11. Bica, D.; Gay, G.; Morando, A.; Soave, E.; Bravdo, B.A. Effect of rootstock and Vitis vinifera genotype on photosynthetic parameters. Acta Hortic. 2000, 526, 373-379. [CrossRef]

12. Paranychianakis, N.V.; Aggelides, S.; Angelakis, A.N. Influence of rootstock, irrigation level and recycled water on growth and yield of Soultanina grapevines. Agric. Water Manag. 2004, 69, 13-27. [CrossRef]

13. Main, G.; Morris, J.; Striegler, K. Rootstock effects on Chardonel productivity, fruit, and wine composition. Am. J. Enol. Vitic. 2002, $53,37-40$.

14. Gonçalves, B.; Moutinho-Pereira, J.; Santos, A.; Silva, A.P.; Bacelar, E.; Correia, C.; Rosa, E. Scion-rootstock interaction affects the physiology and fruit quality of sweet cherry. Tree Physiol. 2006, 126, 93-104. [CrossRef]

15. Zhiyuan, Y. Study on the rootstocks for Fujiminori grape variety. South China 2003, 32, 57-58.

16. Smith, J.P. Investigations Into the Mechanisms Underlying Grapevine Rootstock Effects on Scion Growth and Yield. Ph.D. Thesis, Charles Sturt University, Wagga Wagga, Australia, 2004.

17. Pulko, B.; Vršic, S.; Valdhuber, J. Influence of various rootstocks on the yield and grape composition of sauvignon blanc. Czech J. Food Sci. 2012, 30, 467-473. [CrossRef]

18. Kubota, N.; Li, X.G.; Yasui, K. Effects of rootstocks on sugar, organic acid, amino acid, and anthocyanin contents in berries of potted 'Fujiminori' grapes. J. Jpn. Soc. Hortic. Sci. 1993, 62, 363-370. [CrossRef]

19. Wolpert, J.; Walker, A.; Weber, E.; Bettiga, L.; Smith, R.; Verdegaal, P. Rootstocks and Phylloxera; Viticultural Notes; University of California Cooperative Extension: Napa County, CA, USA, 1994; Number 6.

20. Artés-Hernández, F.; Tomás-Barberán, F.A.; Artés, F. Modified atmosphere packaging preserves quality of $\mathrm{SO}_{2}$-free 'Superior seedless' table grapes. Postharvest Biol. Technol. 2006, 39, 146-154. [CrossRef]

21. Crisosto, C.H.; Corzo, P.; Palou, L.; Mitchel, F.G. Table grape packaging Influences 'flame seedless' and 'redglobe' storage quality. Cent. Vally Postharvest Newsl. 2001, 10, 1-10.

22. Lo'ay, A.A.; Taha, N.A. Evaluation rachis browning phenomena of 'Superior Seedless' vines grafted on different rootstocks during shelf life. Sci. Hortic. 2020, 261, 109040. [CrossRef]

23. A.O.A.C. Association of Official of Analytical Chemist, 15th ed.; A.O.A.C.: Washington, DC, USA, 1995.

24. Lo'ay, A.A.; Taha, N.A.; El-Khateeb, Y.A. Storability of 'Thompson Seedless' grapes: Using biopolymer coating chitosan and polyvinyl alcohol blending with salicylic acid and antioxidant enzymes activities during cold storage. Sci. Hortic. 2019, 249, 314-321. [CrossRef]

25. Miller, G.L. Use of dinitrosalicylic acid reagent for the determination of reducing suga. Anal. Chem. 1959, 31, 426-429. [CrossRef]

26. Collmer, A.; Reid, J.L.; Mount, M.S. Assay methods for pectic enzymes. In Methods in Enzymology; Wood, W.A., Kellogg, S.T., Eds.; Academic Press: San Diego, CA, USA, 1988; Volume 161, pp. 329-335.

27. Bradford, M.M. A rapid and sensitive method for the quantitation of microgram quantities of protein utilizing the principles of protein-dye binding. Anal. Biochem. 1976, 72, 248-254. [CrossRef]

28. Jiang, Y.; Louce, D.C.; Jayas, W.; Lu, W. Effect of chilling temperatures on ethylene binding by banana fruit. Plant Growth Regul. 2004, 43, 109-115. [CrossRef]

29. Ke, D.; Salveit, M.E. The effect of calcium and auxin on russet spotting and phenylalanine ammonia lyase activity in iceberg lettuce. HortiScience 1986, 21, 1169-1171.

30. Hoff, J.F.; Singleton, K.I. A method for determination of tannin in foods by means of immobilized enzymes. J. Food Sci. 1977, 42, 1566-1569. [CrossRef]

31. Iturbe-Ormaetxe, I.; Escuredo, P.R.; Arrese-Igor, C.; Becana, M. Oxidative damage in pea plants exposed to water deficit or paraquat. Plant Physiol. 1998, 116, 173-181. [CrossRef]

32. Lo'ay, A.A. Biological indicators to minimize berry shatter during handling of "Thompson seedless" grapevines. World Appl. Sci. J. 2011, 12, 1107-1113.

33. Rogiers, S.; Hatfield, J.; Jaudzems, V.; White, R.; Keller, M. Grape berry cv. Shiraz epicuticular wax and transpiration during ripening and preharvest weight loss. Am. J. Enol. Vitic. 2004, 55, 121-127.

34. Ritenour, M.A.; Stover, E.; Boman, B.J.; Bowman, K.D.; Castle, W.S. Effect of rootstock on stem-end rind breakdown and decay of fresh citrus. Horttechnology 2004, 13, 315-319. [CrossRef]

35. Gao, H.; Zhang, Z.; Lv, X.; Cheng, N.; Peng, B.; Cao, W. Effect of 24-epibrassinolide on chilling injury of peach fruit in relation to phenolic and proline metabolisms. Postharvest Biol. Technol. 2016, 111, 390-397. [CrossRef] 
36. Tomas-Barberan, F.A.; Gil, M.I.; Castaner, M.; Artes, F.; Saltveit, M.E. Effect of selected browning inhibitors on phenolic metabolism in stem tissue of harvested lettuce. J. Agric. Food Chem. 1997, 45, 583-589. [CrossRef]

37. Zhishen, J.; Mengcheng, T.; Jianming, W. The determination of flavonoid contents in mulberry and their scavenging effects on superoxide radicals. Food Chem. 1999, 64, 555-559. [CrossRef]

38. Lo'ay, A.A.; Dawood, H.D. Minimize browning incidence of banana by postharvest active chitosan/PVA Combines with oxalic acid treatment to during shelf-life. Sci. Hortic. 2017, 226, 208-215. [CrossRef]

39. Bassetto, E.; Jacomino, A.P.; Pinheiro, A.L.; Kluge, R.A. Delay of ripening of 'Pedro Sato' guava with 1-methylcyclopropene. Postharvest Biol. Technol. 2005, 35, 303-308. [CrossRef]

40. Nunan, K.J.; Sims, I.M.; Bacic, A.; Robinson, S.P.; Fincher, G.B. Changes in Cell Wall Composition during Ripening of Grape Berries. Plant Physiol. 1998, 118, 783-792. [CrossRef] [PubMed]

41. Köse, B.; Karabulut, B.; Ceylan, K. Effect of rootstock on grafted grapevine quality. Eur. J. Hortic. Sci. 2014, 79, 197-202.

42. EL-Gendy, H.A. The universal associative envelope of the anti-Jordan triple system of $\mathrm{n} \times \mathrm{n}$ matrices. J. Algebra 2013, 383, 1-28. [CrossRef]

43. Bugaud, C.; Deverge, E.; Daribo, M.-O.; Ribeyre, F.; Fils-Lycaon, B.; Mbéguié-A-Mbéguié, D. Sensory characterisation enabled the first classification of dessert bananas. J. Sci. Food Agric. 2011, 91, 992-1000. [CrossRef] [PubMed]

44. Wills, R.B.H.; Lim, J.S.K.; Greenfield, H. Composition of Australian foods. 31. Tropical and sub-tropical fruit. Food Technol. Aust. 1986, 38, 118-123.

45. Foyer, C.H.; Noctor, G. Oxidant and antioxidant signalling in plants: A re-evaluation of the concept of oxidative stress in a physiological context. Plant. Cell Environ. 2005, 28, 1056-1071. [CrossRef]

46. Foyer, C.H.; Ruban, A.V.; Noctor, G. Viewing oxidative stress through the lens of oxidative signalling rather than damage. Biochem. J. 2017, 474, 877-883. [CrossRef]

47. Hodges, D.M.; Lester, G.E.; Muneo, K.D.; Toivonen, P.M. Oxidative stress: Importance for postharvest quality. HortScience 2004, 39, 924-929. [CrossRef]

48. McCollum, T.; Bowman, K.; Castle, W. Effects of rootstock on fruit quality and postharvest behavior of 'Marsh' grapefruit. Proc. Fla. State Hortic. Soc. 2002, 115, 44-46.

49. Satisha, J.; Doshi, P.; Adsule, P.G. Influence of rootstocks on changing the pattern of phenolic compounds in Thompson seedless grapes and its relationship to the incidence of powdery mildew. Turk. J. Agric. For. 2008, 32, 1-9. [CrossRef]

50. Promyou, S.; Ketsa, S.; Van Doorn, W.G. Effect of surface coating on ripening and early peel spotting in 'sucrier' banana (Musa acuminata). N. Z. J. Crop Hortic. Sci. 2007, 35, 259-265. [CrossRef]

51. Barden, C.L.; Bramlage, W.J. Acclimation of antioxidants in apple peel as related to preharvest factors and superficial scald susceptibility of the fruit. J. Am. Soc. Hortic. Sci 1994, 119, 264-269. [CrossRef]

52. Berlett, B.S.; Stadtman, E.R. Protein oxidation in aging, disease, and oxidative stress. J. Biol. Chem. 1997, 272, $20313-20316$. [CrossRef]

53. Lo'ay, A.A.; Dawood, H.D. Chilling injury, fruit color maturity stages, and antioxidant enzyme activities of lemon 'baladi CV' fruits under cold storage stress. Sci. Hortic. 2019, 257, 108676. [CrossRef]

54. Shewfelt, R.L.; Del Rosario, B.A. The role of lipids peroxidation in storage disorders of freash fruits and vegetables. HortScience 2000, 35, 575-579. [CrossRef] 